\title{
In vitro Ploidy Manipulation for Crop Improvement
}

\author{
Darren H. Touchell*, Irene E. Palmer and Thomas G. Ranney \\ Mountain Crop Improvement Lab, Department of Horticultural Science, Mountain Horticultural Crops Research \\ and Extension Center, North Carolina State University, Mills River, NC, United States
}

In vitro regeneration systems provide a powerful tool for manipulating ploidy to facilitate breeding and development of new crops. Polyploid induction can expand breeding opportunities, assist with the development of seedless triploid cultivars, enhance ornamental characteristics and environmental tolerances, increase biomass and restore fertility in wide hybrids. In vitro ploidy manipulation is commonly induced using antimitotic agents such as colchicine, oryzalin and trifluralin, while many other antimitotic agents have been relatively unexplored. Successful induction requires a synergistic pairing of efficient penetration of the antimitotic agent and may be dependent the length of exposure and concentrations of antimitotic agents, tissue types, and interactions with basal media and plant growth regulators. In vitro conditions vary among taxa and individual genera, species, and cultivars, often requiring unique treatments to maximize polyploid induction. In some taxa, the induction of polyploidy influences in vitro growth, development, and root formation. Here we provide an overview of mitotic inhibitors and their application for in vitro ploidy manipulation for plant breeding and crop improvement.

Keywords: chromosome doubling, in vitro regeneration, mitotic inhibitor, plant breeding, polyploidy, whole genome duplication

\section{INTRODUCTION}

Polyploidy, the condition of having more than two sets of chromosomes, has long been recognized as a major driver of plant evolution and speciation (Soltis et al., 2009). Naturally occurring polyploids have been identified in a wide range of taxa and recent estimates suggest that almost all extant angiosperms have experienced polyploid events in their evolutionary history (Soltis and Burleigh, 2009). Potential evolutionary/adaptive advantages of being polyploid include increased heterosis, gene redundancy and mutational robustness, and phenotypic plasticity (Comai, 2005; Sattler et al., 2015).

The artificial induction of polyploidy can provide a valuable tool to assist with understanding evolutionary processes and to facilitate plant breeding and improvement programs. Polyploids often possess improved traits, such as thicker, darker-colored leaves; larger, longer-lasting flowers and thicker petals; enhanced vigor; improved tolerances to environmental stresses, pests and pathogens; increased metabolite production and may restore fertility in sterile wide hybrids (Kehr, 1996; Comai, 2005; Ranney, 2006; Banyai et al., 2009). However, incorporating polyploids into plant breeding programs often necessitates the induction of new polyploids.

In vitro chromosome doubling has predominantly been induced using the antimitotic agent colchicine. However, the herbicides oryzalin and trifluralin, are often preferred due to their reduced toxicity, higher affinity to plant tubulins, and effectiveness at lower concentrations. The success of in vitro chromosome doubling protocols is dependent upon the effectiveness of antimitotic 
agents to temporarily arrest cell division (cytokinesis) in actively growing tissue. While the length of exposure and concentrations of antimitotic agents is critical for chromosome doubling, several other factors such as tissue types, methods of application, culture conditions and species differences may influence the efficacy of in vitro chromosome doubling. Species-specific in vitro chromosome doubling protocols for diverse and valuable taxa have been widely reported (Table 1). In this review we will explore mitotic inhibitors and examine factors that impact in vitro polyploid manipulation and provide possible areas for further research.

\section{HISTORY}

Artificial induction of polyploids in plants was first reported in the late 1930s with Blakeslee and Avery (1937) demonstrating the use of colchicine for chromosome doubling of several species. Numerous studies investigating colchicine for ploidy manipulation soon followed this initial report (see Dunham and Banta, 1940). The interest in polyploidy grew rapidly, and in 1941, The American Naturalist published the 'Symposium on theoretical and practical aspects of polyploidy in crop plants' (The American Naturalist, 1941). In that issue, Emsweller and Ruttle (1941) first discussed the value of induced polyploidy for the improvement of ornamental plants. Since these early studies chromosome doubling has become an integral component of breeding programs for many economically important crops.

Advancements in plant tissue culture in the 1960s provided new opportunities for developing polyploids. Murashige and Nakano (1966) isolated tetraploid cells from the pith of diploid tobacco plants and used in vitro culture to stabilize and produce tetraploid plants. Soon after, Heinz and Mee (1970) reported the use of colchicine to induce polyploid sugarcane cell suspensions. Hussey and Hypher (1978) recovered tetraploid sugar beets by treating in vitro grown plantlets with colchicine. The past two decades have seen a significant increase in the use of in vitro polyploid induction. This increase may be attributed, in part, to the development and proliferation of tissue culture protocols for a diverse range of taxa.

\section{ANTIMITOTIC AGENTS}

In vitro polyploid manipulation is dependent upon disrupting the cell cycle to prevent polar migration of chromosomes during anaphase. Chemicals ranging from caffeine (Thomas et al., 1997) and nitrous oxide (Taylor et al., 1976) to antimicrotubule herbicides have all been shown to induce polyploidy. However, several antimicrotuble compounds, such as colchicine and oryzalin, have been predominantly used for successful in vitro polyploid induction (Table 2).

Colchicine $\quad[N-5,6,7,9$-tetrahydro-1,2,3,10-tetra-methoxy9-oxobenzo(a)heptalen-7-yl] acetamide is perhaps the most commonly used mitotic inhibitor and has been used to recover polyploids in a wide range of species (Table 1). Colchicine is extracted from the bulbs of autumn crocus (Colchicum autumnale) and is widely used as a medication to treat gout and other inflammatory diseases. As an antimitotic agent, colchicine disrupts the cell cycle beginning at metaphase where it destabilizes microtubules by binding to the $\beta$-tubulin subunit to form a colchicine-tubulin complex. As such, colchicine prevents microtubule polymerization, without influencing depolymerization, resulting in degradation of microtubules (Leung et al., 2015). For in vitro chromosome doubling, colchicine has advantages that it is soluble in aqueous solutions, heat-stable, and can be autoclaved and easily applied to plant tissues. However, colchicine has high binding affinity for animal microtubules and is potentially toxic to humans (Morejohn et al., 1984). In contrast, colchicine has relatively low binding affinity to plant microtubules which requires it to be used in high concentrations to maintain effectiveness.

Collectively, certain herbicides provide viable alternatives to colchicine for in vitro ploidy manipulation. It is estimated that approximately $25 \%$ of herbicides act by affecting mitosis (Vaughn and Lehnen, 1991). Herbicides consist of several different chemical classes with antimitotic activity, including dinitroanilines (oryzalin, trifluralin, pendamethalin) (Morejohn et al., 1987; Hugdahl and Morejohn, 1993), phosphorothioamidates (amipro-phos-methyl) (Murthy et al., 1994), benzamides (propyzamide) (Bartels and Hilton, 1973), cyanoacrylates (ethyl (2Z)-3-amino-2-cyano4-ethylhex-2-enoate) (Tresch et al., 2005), and carbonates (chlorpropham, propham).

Dinitroanilines are the most common class of herbicides used for in vitro ploidy manipulation. Dinitroanilines have shown to have high binding affinity to plant tubulins at low concentrations while showing little binding affinity with animal tubulins (Morejohn et al., 1987; Hugdahl and Morejohn, 1993). This group of compounds works similarly to colchicine to disrupt mitosis in metaphase. Dinitroanilines bind to $\alpha$-tubulin to form a tubulindinitroaniline complex to prevent microtubule polymerization.

The dinitroanilines contain numerous compounds that can be divided into symmetric (e.g., oryzalin, trifluralin) and non-symmetric (e.g., pendimethalin) compounds that differentially interact with $\alpha$-tubulin (see Ma et al., 2010). In a comprehensive study evaluating the effect of 12 different dinitroanilines on the unicellular parasite, Toxoplasma gondii, expressing oryzalin sensitive wild-type and $\alpha$-tubulin mutants conferring oryzalin resistance, $\mathrm{Ma}$ et al. (2010) found that non-symmetric compounds dinitramine and pendimethalin demonstrated increased inhibition. Similarly, several trifluralin analogs showed increased binding efficiencies to $\alpha$-tubulin of the unicellular organism Trypanosoma brucei (Giles et al., 2009). These studies have suggested that small speciesspecific differences in the properties of $\alpha$-tubulin binding sites may influence interaction with functional groups of different dinitroanilines.

For plant species, studies have shown that mutations to $\alpha$-tubulin binding sites may alter binding affinities and confer resistance to the dinitroanilines, specifically oryzalin and trfluralin (Anthony and Hussey, 1999; Chu et al., 2018). This may have significance for in vitro ploidy manipulation, as studies have been primarily isolated to oryzalin and trifluralin (Table 1), 
TABLE 1 | Reported in vitro polyploid induction of diverse crops utilizing varied tissues, antimitotic agents and concentrations, and exposure times.

\begin{tabular}{|c|c|c|c|c|c|c|}
\hline Family & Species & Tissue & Agent & Concentration & Exposure & References \\
\hline Actinidiaceae & Actinidia chinensis & $\begin{array}{l}\text { Organogenesis from } \\
\text { petioles }\end{array}$ & Colchicine & $1.25-2.5 \mathrm{mM}$ & $4 \mathrm{~h}$ & Wu et al., 2011 \\
\hline \multirow[t]{2}{*}{ Amaryllidaceae } & Clivia miniate & Immature embryos & Colchicine & $10-50 \mathrm{mM}$ & $10-30$ days & Wang and Lei, 2012 \\
\hline & Allium cepa & Shoot apices & $\begin{array}{l}\text { Colchicine } \\
\text { Oryzalin }\end{array}$ & $\begin{array}{r}2.5 \mathrm{mM} \\
50 \mu \mathrm{M}\end{array}$ & $\begin{array}{l}24 \mathrm{~h} \\
24 \mathrm{~h}\end{array}$ & Geoffriau et al., 1997 \\
\hline \multirow[t]{2}{*}{ Apiaceae } & Centella asiatica & Shoot apices & Colchicine & $1.25-5 \mathrm{mM}$ & $12-24 h$ & Kaensaksiri et al., 2011 \\
\hline & Trachyspermum ammi & Seeds & Colchicine & $0.06-1.25 \mathrm{mM}$ & $6-48 \mathrm{~h}$ & Noori et al., 2017 \\
\hline \multirow[t]{2}{*}{ Araceae } & Spathiphyllum wallsii & Somatic embryos & $\begin{array}{l}\text { Oryzalin } \\
\text { Trifluralin } \\
\text { Colchicine }\end{array}$ & $\begin{array}{c}10 \mu \mathrm{M} \\
10 \mu \mathrm{M} \\
100 \mu \mathrm{M}\end{array}$ & $16 \mathrm{~h}$ & Eeckhaut et al., 2004 \\
\hline & Zantedeschia sp. & Shoot apices & Colchicine & $1.25 \mathrm{mM}$ & $1-4$ days & Cohen and Yao, 1996 \\
\hline Asparagaceae & Ophiopogon planiscapus & Embryogenic callus & Oryzalin & $7.5 \mu \mathrm{M}$ & 3-9 days & Gillooly et al., 2015 \\
\hline \multirow[t]{7}{*}{ Asteraceae } & Echinacea purpurea & $\begin{array}{l}\text { Organogenesis from } \\
\text { petioles }\end{array}$ & Colchicine & $300 \mathrm{mM}$ & 28 days & Nilanthi et al., 2009 \\
\hline & Rudbeckia hirta & Shoot apices & Oryzalin & $15 \mu \mathrm{M}$ & $3-5$ days & $\begin{array}{l}\text { Touchell personal } \\
\text { communication }\end{array}$ \\
\hline & Rudbeckia subtomentosa & Shoot apices & Oryzalin & $15-60 \mu \mathrm{M}$ & $3-5$ days & Palmer et al., 2008 \\
\hline & Rudbeckia maxima & Shoot apices & Oryzalin & $60 \mu \mathrm{M}$ & 3 days & Palmer et al., 2008 \\
\hline & Gerbera jamesonii & Shoots & Colchicine & $2.5-12.5 \mathrm{mM}$ & $2-8 \mathrm{~h}$ & Gantait et al., 2011 \\
\hline & Smallanthus sonchifolius & Nodal segments & $\begin{array}{l}\text { Colchicine } \\
\text { Oryzalin }\end{array}$ & $\begin{array}{c}3 \mathrm{mM} \\
20-25 \mu \mathrm{M}\end{array}$ & 24 h $24-48$ h & $\begin{array}{l}\text { Viehmannová et al., } \\
2009\end{array}$ \\
\hline & Artemisia annua & $\begin{array}{l}\text { Organogenesis from } \\
\text { leaves }\end{array}$ & Colchicine & $25 \mathrm{mM}$ & $24 \mathrm{~h}$ & Banyai et al., 2009 \\
\hline Balsaminaceae & Impatiens walleriana & Shoot apices & Oryzalin & $15-60 \mu \mathrm{M}$ & $12-48 \mathrm{~h}$ & Ghanbari et al., 2019 \\
\hline Bixaxeae & Bixa orellana & Hypocotyl segments & Oryzalin & $15 \mu \mathrm{M}$ & 15 days & de Carvalho et al., 2005 \\
\hline \multirow[t]{3}{*}{ Brassicaceae } & $\begin{array}{l}\text { Raphanus sativus x } \\
\text { Brassica oleracea }\end{array}$ & Shoots & Amiprophos-methyl & $10-30 \mu \mathrm{M}$ & $24 \mathrm{~h}$ & Niimi et al., 2015 \\
\hline & $\begin{array}{l}\text { Brassica oleraceae var. } \\
\text { capitate }\end{array}$ & Root cultures & Colchicine & $5-10 \mathrm{mM}$ & $3-12 \mathrm{~h}$ & Yuan et al., 2015 \\
\hline & $\begin{array}{l}\text { Brassica oleraceae var. } \\
\text { italica }\end{array}$ & Root cultures & Colchicine & $1.25 \mathrm{mM}$ & $6-12 h$ & Yuan et al., 2015 \\
\hline \multirow[t]{2}{*}{ Cannabaceae } & Humulus lupulus & Shoot apices & Colchicine & $0.25-2.5 \mathrm{mM}$ & $24-72$ h & $\begin{array}{l}\text { Trojal-Golush and } \\
\text { Skomra, } 2013\end{array}$ \\
\hline & Cannabis sativa & Shoot apices & Oryzalin & $20-60 \mu \mathrm{M}$ & $24 \mathrm{~h}$ & Parsons et al., 2019 \\
\hline \multirow[t]{2}{*}{ Caryophyllaceae } & Lychnis senno & Nodal segments & Colchicine & $0.25-1.25 \mu \mathrm{M}$ & 3 days & Chen et al., 2006 \\
\hline & Dianthus caryophyllus & Nodal segments & APM & $32.9 \mu \mathrm{M}$ & $24 \mathrm{~h}$ & Nimura et al., 2006 \\
\hline \multirow[t]{3}{*}{ Cucurbitaceae } & Citrullus lanatus & Hypocotyl segments & Colchicine & $0.25 \mathrm{mM}$ & 4 days & Raza et al., 2003 \\
\hline & Citrullus lanatus & Shoot apices & $\begin{array}{l}\text { Colchicine } \\
\text { Oryzalin } \\
\text { Ethalfluralin } \\
\text { Butralin } \\
\text { Dinitramine }\end{array}$ & $\begin{array}{l}1.5-2.5 \mu \mathrm{mM} \\
25-100 \mu \mathrm{M} \\
25-100 \mu \mathrm{M} \\
25-100 \mu \mathrm{M} \\
25-100 \mu \mathrm{M}\end{array}$ & $\begin{array}{l}3-9 \text { days } \\
3-9 \text { days } \\
3-9 \text { days } \\
3-9 \text { days } \\
3-9 \text { days }\end{array}$ & Nasr et al., 2004 \\
\hline & Cucumis sativus & $\begin{array}{l}\text { Nodal segments/shoot } \\
\text { apices }\end{array}$ & $\begin{array}{l}\text { Colchicine } \\
\text { Oryzalin } \\
\text { Trifluralin }\end{array}$ & $\begin{array}{c}0.6-3.75 \mathrm{mM} \\
15-433 \mu \mathrm{M} \\
15-450 \mu \mathrm{M}\end{array}$ & $\begin{array}{l}18-36 \mathrm{~h} \\
18-36 \mathrm{~h} \\
18-36 \mathrm{~h}\end{array}$ & $\begin{array}{l}\text { Ebrahimzadeh et al., } \\
2018\end{array}$ \\
\hline \multirow[t]{3}{*}{ Ericaceae } & $\begin{array}{l}\text { Rhododendron } \\
\text { 'Frangrantissimum } \\
\text { Improved' }\end{array}$ & Organogenic callus & Oryzalin & 7.5 & 14 days & Hebert et al., 2010 \\
\hline & Rhododendron & Seedlings & $\begin{array}{l}\text { Oryzalin } \\
\text { Trifluralin }\end{array}$ & $\begin{array}{l}0.3 \mathrm{mM} \\
0.3 \mathrm{mM}\end{array}$ & $\begin{array}{l}3 \text { days } \\
3 \text { days }\end{array}$ & Eeckhaut et al., 2002 \\
\hline & Rhododendron & Shoots & Oryzalin & $30 \mu \mathrm{M}$ & $24 \mathrm{~h}$ & Väinölä, 2000 \\
\hline Fabaceae & Cercis glabra & Shoot apices & Oryzalin & $150 \mu \mathrm{M}$ & $12-96 \mathrm{~h}$ & Nadler et al., 2012 \\
\hline Haemodoraceae & Anigozanthos sp. & Axillary buds & Colchicine & $2.5 \mathrm{mM}$ & 7 days & Griesbach, 1990 \\
\hline \multirow[t]{2}{*}{ Hydrangea } & Hydrangea macrophylla & Apical shoot & Oryzalin & $15-30 \mu \mathrm{M}$ & $3-5$ days & $\begin{array}{l}\text { Touchell personal } \\
\text { communication }\end{array}$ \\
\hline & Hydrangea arborescence & Apical shoot & Oryzalin & $15-30 \mu \mathrm{M}$ & $3-5$ days & $\begin{array}{l}\text { Touchell personal } \\
\text { communication }\end{array}$ \\
\hline Hypericaceae & Hypericum sp. & Organogenic callus & Oryzalin & $30 \mu \mathrm{M}$ & 6 days & Meyer et al., 2009 \\
\hline Iridaceae & Crocosmia aurea & Seed & Colchicine & $0.25-25 \mu \mathrm{M}$ & $12 \mathrm{~h}-3$ days & Hannweg et al., 2013 \\
\hline
\end{tabular}


TABLE 1 | Continued

\begin{tabular}{|c|c|c|c|c|c|c|}
\hline Family & Species & Tissue & Agent & Concentration & Exposure & References \\
\hline & Watsonia lepida & Hypocotyl segments & Oryzalin & $25-250 \mu \mathrm{M}$ & $1-3$ days & Ascough et al., 2008 \\
\hline \multirow[t]{3}{*}{ Lamiaceae } & Thymus persicus & Shoot apices & Colchicine & $0.75-1.25 \mathrm{mM}$ & $12-48 h$ & Tavan et al., 2015 \\
\hline & Tetradenia riparia & Seed & Colchicine & $0.025-0.25$ mM & $12-72 \mathrm{~h}$ & Hannweg et al., 2016b \\
\hline & Plectranthus esculentus & Nodal segments & Colchicine & $0.025250 \mathrm{mM}$ & $12-72$ h & Hannweg et al., 2016a \\
\hline \multirow[t]{3}{*}{ Liliaceae } & Tulipa gesneriana & Flower stems & Oryzalin & $1.44-28.8 \mu \mathrm{M}$ & $1-14$ days & Chauvin et al., 2005 \\
\hline & Lilium hybrid & Bulb segments & Oryzalin & $30-200 \mu \mathrm{M}$ & $2-6 h$ & Chandanie et al., 2011 \\
\hline & Linum album & Nodal segments & Colchicine & $1.25-5 \mathrm{mM}$ & $24-96 \mathrm{~h}$ & Javadian et al., 2017 \\
\hline ıLythraceae & Lagerstroemia indica & Nodal segments & Colchicine & $0.25-0.75 \mathrm{mM}$ & 10 days & Zhang et al., 2010 \\
\hline Oleaceae & Syringa sp. & Nodal segments & Colchicine & $0.05-0.25 \mathrm{mM}$ & $1-2$ days & Rose et al., 2000 \\
\hline \multirow[t]{2}{*}{ Orchidaceae } & Bletilla striata & Protocorms & Colchicine & $1.25-5 \mathrm{mM}$ & $12-48 h$ & Pan-pan et al., 2018 \\
\hline & $\begin{array}{l}\text { Dendrobium } \\
\text { chrysotoxum }\end{array}$ & Protocorms & Colchicine & $1.0 \mathrm{mM}$ & $24 \mathrm{~h}$ & Artichart, 2013 \\
\hline Passifloroideae & Passiflora edulis & Hypocotyl segments & $\begin{array}{l}\text { Colchicine } \\
\text { Oryzalin }\end{array}$ & $\begin{array}{c}0.025- \\
1.25 \mathrm{mM} \\
5-30 \mu \mathrm{M}\end{array}$ & $\begin{array}{l}15 \text { days } \\
15 \text { days }\end{array}$ & Rêgo et al., 2011 \\
\hline Plantaginaceae & Hebe 'Oratia Beauty' & Nodal segments & $\begin{array}{l}\text { Colchicine } \\
\text { Oryzalin }\end{array}$ & $\begin{array}{c}0.5-1.0 \mathrm{mM} \\
11.5-289 \mu \mathrm{M}\end{array}$ & $\begin{array}{l}48 h \\
48 h\end{array}$ & Gallone et al., 2014 \\
\hline Plumbaginoidaceae & Plumbago auriculata & Shoot apices & Pendimethalin & $800 \mu \mathrm{M}$ & 7 days & Jiang et al., 2020 \\
\hline Poaceae & Miscanthus sinensis & Shoots & $\begin{array}{l}\text { Colchicine } \\
\text { Oryzalin }\end{array}$ & $\begin{array}{l}313 \mu \mathrm{M} \\
5-15 \mu \mathrm{M}\end{array}$ & $\begin{array}{l}18 \mathrm{~h} \\
4-7 \text { days }\end{array}$ & Petersen et al., 2002, 2003 \\
\hline \multirow[t]{3}{*}{ Poaceae } & Miscanthus x giganteus & Shoots & Oryzalin & $15 \mu \mathrm{M}$ & $3-5$ days & Touchell and Ranney, 2012 \\
\hline & Panicum virgatum & Embryogenic callus & Colchicine & $1 \mathrm{mM}$ & 13 days & Yang et al., 2014 \\
\hline & Triticum aestivum & Microspore culture & Colchicine & $3 \mathrm{mM}$ & $24-48 h$ & Hansen and Andersen, 1998 \\
\hline Polemoniaceae & Phlox subulata & Shoot apices & Colchicine & $0.125-1.0 \mathrm{mM}$ & 10-30 days & Zhang et al., 2008 \\
\hline \multirow[t]{3}{*}{ Ranunculaceae } & Ranunculus asiaticus & Shoots & $\begin{array}{l}\text { Colchicine } \\
\text { Oryzalin } \\
\text { Trifluralin }\end{array}$ & $\begin{array}{c}100-200 \mu \mathrm{M} \\
0.5-3.0 \mu \mathrm{M} \\
2.0 \mu \mathrm{M}\end{array}$ & $\begin{array}{c}16-24 \mathrm{~h} \\
6-10 \text { weeks } \\
6-10 \text { weeks }\end{array}$ & Dhooghe et al., 2009a \\
\hline & Helleborus niger & Shoots & $\begin{array}{l}\text { Oryzalin } \\
\text { Trifluralin }\end{array}$ & $3 \mu \mathrm{M} 3-10 \mu \mathrm{M}$ & & Dhooghe et al., 2009b \\
\hline & Helleborus $x$ nigercors & Shoots & $\begin{array}{l}\text { Oryzalin } \\
\text { Trifluralin }\end{array}$ & $3 \mu \mathrm{M} 3-10 \mu \mathrm{M}$ & & Dhooghe et al., 2009b \\
\hline Rhamnaceae & Ziziphus jijuba & Shoot apices & Colchicine & $1.25-2.5$ & $24-72 \mathrm{~h}$ & Gu et al., 2005 \\
\hline \multirow[t]{9}{*}{ Rosaceae } & Rosa 'Therese Bugnet' & $\begin{array}{l}\text { Shoot apices/nodal } \\
\text { segments }\end{array}$ & Oryzalin & $5-15 \mu \mathrm{M}$ & 14-28 days & Kermani et al., 2003 \\
\hline & Rosa rugosa & Nodal segments & Oryzalin & $5 \mu \mathrm{M}$ & $12 \mathrm{~h}$ & Allum et al., 2007 \\
\hline & Rosa hybrida & Nodal segments & $\begin{array}{l}\text { Oryzalin } \\
\text { Trifluralin } \\
\text { APM }\end{array}$ & $\begin{array}{l}6-24 \mu \mathrm{M} \\
6-24 \mu \mathrm{M} \\
6-24 \mu \mathrm{M}\end{array}$ & $12-48 \mathrm{~h}$ & Khosravi et al., 2008 \\
\hline & Rosa persica & Nodal segments & $\begin{array}{l}\text { Trifluralin } \\
\text { APM }\end{array}$ & $\begin{array}{l}6-24 \mu \mathrm{M} \\
6-24 \mu \mathrm{M}\end{array}$ & $12-48 h$ & Khosravi et al., 2008 \\
\hline & Chaenomeles japonica & Nodal segments & $\begin{array}{l}\text { Oryzalin } \\
\text { Colchicine }\end{array}$ & $\begin{array}{c}10-50 \mu \mathrm{M} \\
0.25-38 \mathrm{mM}\end{array}$ & $1-2$ days & Stanys et al., 2006 \\
\hline & Prunus laurocerasus & Shoots & Oryzalin & $150 \mu \mathrm{M}$ & $1-2$ days & $\begin{array}{l}\text { Contreras and Meneghelli, } \\
2016\end{array}$ \\
\hline & Malus $\times$ domestica & Axillary buds & Colchicine & $10 \mathrm{mM}$ & 2 days & Hias et al., 2017 \\
\hline & Pyrus pyriflora & Shoots & Colchicine & $0.25 \mathrm{mM}$ & $1-8$ days & Kadota and Niimi, 2002 \\
\hline & Pyrus communis & $\begin{array}{l}\text { Organogenesis from } \\
\text { leaf }\end{array}$ & Colchicine & $1 \mathrm{mM}$ & $24-72 \mathrm{~h}$ & Sun et al., 2009 \\
\hline \multirow[t]{2}{*}{ Salicaceae } & Populus sp. & $\begin{array}{l}\text { Organogenesis from } \\
\text { leaves }\end{array}$ & Colchicine & $50-100 \mu \mathrm{M}$ & $2-4$ days & Xu et al., 2016 \\
\hline & Populus hopeiensis & $\begin{array}{l}\text { Organogensis from } \\
\text { leaves }\end{array}$ & Colchicine & $100 \mu \mathrm{M}$ & $96 \mathrm{~h}$ & Wu et al., 2020 \\
\hline Sapindaceae & Acer platanoides & Nodal segments & Oryzalin & $15 \mu \mathrm{M}$ & 3 days & Lattier et al., 2013 \\
\hline Scrophulariaceae & Buddleja sp. & Nodal segments & Oryzalin & $3-7 \mu \mathrm{M}$ & $1-3$ days & Dunn and Lindstrom, 2007 \\
\hline Solanaceae & Petunia axillaris & Leaves, organogenesis & Colchicine & $0.2 \mathrm{mg}$ & 15 days & Regalado et al., 2017 \\
\hline Vitaceae & Vitis sp. & Shoots & Colchicine & $1.25 \mathrm{mM}$ & $24-48 \mathrm{~h}$ & Notsuka et al., 2000 \\
\hline Zingiberaceae & Hedychium muluense & Embryogenic callus & $\begin{array}{l}\text { Colchicine } \\
\text { Oryzalin }\end{array}$ & $\begin{array}{c}2.5 \mathrm{mM} \\
20-120 \mu \mathrm{M}\end{array}$ & $\begin{array}{l}1-3 \text { days } \\
1-3 \text { days }\end{array}$ & Sakhanokho et al., 2009 \\
\hline
\end{tabular}


TABLE 2 | Mitotic inhibitors that are used or have potential to interfere with the cell cycle to induce polyploids.

\begin{tabular}{|c|c|c|}
\hline Mitotic inhibitor & Mode of action & Application \\
\hline \multicolumn{3}{|l|}{ Miscellaneous } \\
\hline Colchicine & Destabilizes $\beta$-tubulin & Seeds, shoots, see Table 1 \\
\hline Taxol & Stabilizes $\beta$-tubulin & $\begin{array}{l}\text { Not reported for plant } \\
\text { polyploidy }\end{array}$ \\
\hline Nitrous oxide & $\begin{array}{l}\text { Possible interacts with } \\
\alpha \text {-tubulin }\end{array}$ & Seeds Taylor et al. (1976) \\
\hline \multicolumn{3}{|l|}{ Dinitroanilines } \\
\hline Oryzalin & Destabilizes $\alpha$-tubulin & $\begin{array}{l}\text { Seeds, nodal segments, } \\
\text { shoots, callus, see Table } 1 \\
\text { for examples }\end{array}$ \\
\hline Trifluralin & Destabilizes $\alpha$-tubulin & $\begin{array}{l}\text { Nodal segments, shoots, } \\
\text { callus, see Table } \mathbf{1} \text { for } \\
\text { examples }\end{array}$ \\
\hline Pendimethalin & Destabilizes $\alpha$-tubulin & $\begin{array}{l}\text { Limited use, Micro-shoots } \\
\text { of Nepta (Mitrofanova et al., } \\
\text { 2003) }\end{array}$ \\
\hline Ethalfluralin & Destabilizes $\alpha$-tubulin & $\begin{array}{l}\text { Limited use, Micro-shoots } \\
\text { of Nepta (Mitrofanova et al., } \\
\text { 2003) }\end{array}$ \\
\hline \multicolumn{3}{|l|}{ Benzamides } \\
\hline Propyzamide & Destabilizes $\alpha$-tubulin & $\begin{array}{l}\text { Nodal segments of Vitis } \\
\text { davidii (Cai et al., 2016) }\end{array}$ \\
\hline \multicolumn{3}{|l|}{ Phosphorothioates } \\
\hline $\begin{array}{l}\text { Amiprophos-methyl } \\
\text { (APM) }\end{array}$ & $\begin{array}{l}\text { Destabilizes } \alpha \text {-tubulin, } \\
\text { same binding site as } \\
\text { oryzalin }\end{array}$ & $\begin{array}{l}\text { Nodal segments (Nimura } \\
\text { et al., 2006) }\end{array}$ \\
\hline \multicolumn{3}{|l|}{ Cyanoacrylates } \\
\hline $\begin{array}{l}\text { Ethyl (2Z)-3-amino-2- } \\
\text { cyano-4-ethylhex-2- } \\
\text { enoate (CA1) }\end{array}$ & $\begin{array}{l}\text { Destabilizes } \alpha \text {-tubulin, } \\
\text { same binding site as } \\
\text { oryzalin }\end{array}$ & $\begin{array}{l}\text { No reports for plant } \\
\text { polyploid induction }\end{array}$ \\
\hline \multicolumn{3}{|l|}{ Carbamates } \\
\hline Propham & $\begin{array}{l}\text { Disrupt and fragment } \\
\text { spindle poles }\end{array}$ & $\begin{array}{l}\text { No reports for plant } \\
\text { polyploid induction }\end{array}$ \\
\hline \multicolumn{3}{|l|}{$\begin{array}{l}\text { Proteasome } \\
\text { inhibitors }\end{array}$} \\
\hline Lactacystin & $\begin{array}{l}\text { Interfere with regulatory } \\
\text { proteins that govern } \\
\text { metaphase, anaphase and } \\
\text { cytokinesis transitions }\end{array}$ & $\begin{array}{l}\text { No reports for plant } \\
\text { polyploid induction }\end{array}$ \\
\hline MG132 & Same as lactacystin & $\begin{array}{l}\text { No reports for plant } \\
\text { polyploid induction }\end{array}$ \\
\hline \multicolumn{3}{|l|}{ Cancer drugs } \\
\hline Reversine & $\begin{array}{l}\text { Inhibits anaphase in human } \\
\text { breast tissue to form } \\
\text { polyploid cells }\end{array}$ & $\begin{array}{l}\text { No reports for plant } \\
\text { polyploid induction }\end{array}$ \\
\hline
\end{tabular}

with only limited reports of alternative dinitroanilines such as pendamethalin (Ren et al., 2018), dinitramine (Nasr et al., 2004), ethylfluralin (Mitrofanova et al., 2003), and butralin (Nasr et al., 2004). With the structural diversity in dinitroanilines, different compounds may provide higher efficacy for recovering polyploids in recalcitrant species.

The phosphoric amides are another group of herbicides with antimitotic activity, of which amiprophos-methyl (APM) has been used for in vitro chromosome doubling (Khosravi et al., 2008). Amiprophos-methyl has shown high affinity for tobacco $\alpha$-tubulin and may target the same binding sites as oryzalin
(Murthy et al., 1994). An advantage of APM is that it has increased solubility in water compared to dinitroanilines, thus reducing the use of additional solvents. Similarly, the benzamides, particularly propyzamide have shown potential for in vitro chromosome doubling (Cai et al., 2016). Propyzamide also targets the same binding sites as oryzalin (Bartels and Hilton, 1973). Cyanoacrylates are another class of antimitotic agents that have the same mechanisms as dinitroanilines (Tresch et al., 2005). Similar to APM and propyzamide, the cyanoacrylates, ethyl (2Z)3-amino-2-cyano-4-ethylhex-2-enoate (CA1) and CA2 bind to $\alpha$-tubulin at the same sites as oryzalin (Tresch et al., 2005). However, they have yet to be used for in vitro polyploid induction.

Nitrous oxide has also been reported to induce polyploids (Taylor et al., 1976). The mode of action has remained unclear. However, Kitamura et al. (2009) suggested that nitrous oxide may induce polyploidy by inhibiting microtubule polymerization. It is likely that nitrous oxide interacts with tyrosine to form nitrotyrosine (Neill et al., 2003). Nitrotyrosine may replace tyrosine in $\alpha$-tubulin and influence polymerization (Blume et al., 2013; Lipka and Müller, 2014). Lipka and Müller (2014) found that in Arabidopsis thaliana nitrotyrosine alone inhibited microtubule polymerization, but reduced sensitivity to oryzalin due to changes in $\alpha$-tubulin binding sites. However, Jovanović et al. (2010) demonstrated that nitrotyrosine increased sensitivity of Nicotiana tabacum L. cell cultures to oryzalin, suggesting nitrotyrosine could provide addition antimicrotubule qualities.

In contrast to antimicrotubule agents, the carbamate herbicides, such as propham or chlorpropham, act to disrupt mitosis without influencing the polymerization or destabilization of microtubules. Rather, carbamates act to disrupt and fragment spindle poles throughout the cell resulting in a multipolar, rather than bipolar, migration of chromosomes (Vaughn and Lehnen, 1991). As such, it is unlikely that carbamates will be effective in the development of polyploids.

There are no reports of the use of proteasome inhibitors being utilized for vitro ploidy manipulation. However, proteasome inhibitors such as lactacystin and MG132, interfere with key regulatory proteins that govern the metaphase, anaphase and cytokinesis transitions (Planchais et al., 2000). A drawback of proteasome inhibitors is that treatments are not fully reversible (Planchais et al., 2000).

Another group of cell cycle inhibitors, including hydroxyurea and aphididcolin, act to arrest cell cycle at the beginning of $\mathrm{S}$-phase. Following the removal of the inhibitor, cells progress through $S, G_{2}$, and $M$ phase in a synchronized manner (Darzynkiewicz et al., 2011). While these compounds do not directly affect polyploidy, they may have utility as treatments to facilitate synchronizing the cell cycle and maximize the number of cells affected by the antimicrotubule agent thereby reducing cytochimeras.

\section{IN VITRO POLYPLOID INDUCTION - AN OVERVIEW}

The success of in vitro polyploid induction is highly integrated with the development of efficient in vitro culture protocols. Plant 
tissue culture systems have often proven difficult for many taxa, especially woody plants and only a limited number of species have successfully been grown in tissue culture. Protocol development often needs to be conducted for each species and often for each clone to optimize regeneration protocols that can be applied for in vitro polyploid induction. Nonetheless, successful chromosome doubling has been achieved for a significant number of species representing a diverse range of families and genera (Table 1).

\section{KEY VARIABLES INFLUENCING IN VITRO POLYPLOID INDUCTION}

\section{Tissue Type}

In vitro ploidy manipulation is highly dependent on the availability of successful in vitro regeneration systems. Although apical meristems can be treated in vitro, regeneration via somatic embryogenesis or shoot organogenesis is highly desirable for polyploid induction treatments. The ability to regenerate an entire plant from a single or only a few cells can improve the development of homogenous polyploid plants and minimizes the possibility of cytochimeras. Organogenic or embryogenic regeneration systems have been used for chromosome doubling for several species (Table 1). For Echinacea purpurea, polyloids were regenerated from petioles treated with colchicine (Nilanthi et al., 2009). Similarly, organogenesis from Populus sp. leaves treated with oryzalin resulted in polyploids. Sakhanokho et al. (2009) treated embryogenic callus of Hedychium muluense with colchicine or oryzalin to develop homogeneous polyploids. Further, in vitro regeneration systems are essential for developing dihaploids. Hansen and Andersen (1998) regenerated dihaploids from microspores of Triticum aestivum treated with colchicine. In an alternative approach, Yuan et al. (2015) regenerated dihaploids from in vitro roots treated with colchicine of haploid Brassica sp.

In vitro regeneration systems via organogenesis and somatic embryogenesis, however, have only been developed for relatively few species, and this approach may result in greater somaclonal variation due to mutations and epigenetic changes (Bairu et al., 2007). For many crops, the development of in vitro regeneration systems provides unique challenges and alternative tissues may need to be considered. As such, nodal segments and shoot apices have been the most widely used tissues for in vitro chromosome doubling (Table 1).

To obtain homogenous polyploids using nodal segments and shoot apices, all initial cells within the three histogenic layers of the meristems need to be affected by the antimitotic agent (Dermen, 1953; Klekowski, 2003). If all the initial cells are not affected, mixoploids or cytochimeras may form. Mixoploids have been widely observed in in vitro chromosome doubling of a wide range of species, including; Acer platanoides (Lattier et al., 2013), Helleborus sp. (Dhooghe et al., 2009b), Hypericum sp. (Meyer et al., 2009), Lagerstroemia indica (Zhang et al., 2010), Rhododendron hybrids (Väinölä, 2000; Hebert et al., 2010), Rosa rugosa (Allum et al., 2007), Ranunculus asiaticus
(Dhooghe et al., 2009a), Tulipa gesneriana (Chauvin et al., 2005), and Vitis sp. (Notsuka et al., 2000; see Table 1).

Mixoploid tissue are often unstable and have a high tendency for diplontic selection and may revert to their original ploidy. Diplontic selection may occur when diploid (or lower ploidy) cells (having less DNA) can replicate and divide faster than neighboring higher ploidy cells (Dermen, 1953; Klekowski, 2003). Over time, the proportion of lower ploidy cells increases resulting in the loss of converted cells. For example, Hussey and Hypher (1978) documented cytochimeral sugar beets after treatment with colchicine and observed that polyploid cells disappeared over subsequent subcultures. Similarly, Lattier et al. (2013) found that for Acer platanoides, mixoploid tissues reverted to diploids over a 6-month period.

Another approach is to treat seeds with antimitotic inhibitors prior to establishing in vitro cultures. Hannweg et al. (2013) treated Crocosmia aurea seed with $0.25 \mu \mathrm{M}$ colchicine overnight or $25 \mu \mathrm{M}$ colchicine for 3 days before using introducing them into tissue culture. The highest induction of homogenous tetraploids (29.82\%) was achieved with $0.25 \mu \mathrm{M}$ overnight.

\section{Selection and Exposure to Antimitotic Agents}

Polyploid induction is highly variable between species and cultivars and is dependent upon antimitotic agent, tissue type, and culture conditions (Table 1). While the dinitroaniline herbicides have a high affinity for plant tubulins and, more recently, have been increasingly used for in vitro chromosome doubling, colchicine remains a highly effective mitotic agent for many species. Morejohn et al. (1984) showed that binding efficiencies of colchicine to plant tubulins varied substantially between species, and colchicine still remains the most efficient and preferred antimitotic agents for species such as Populus hopeiensis (Wu et al., 2020).

Cholchicine is clearly the most used antimitotic agent (Table 1), regardless of the well-documented negative drawbacks (Dhooghe et al., 2009a), and has been used for a diverse species ranging from herbaceous (e.g., Echinacea purpurea; Nilanthi et al., 2009) to woody crops (e.g., Chaenomeles japonica; Stanys et al., 2006). The wide success of colchicine as an antimitotic inhibitor has led to its continued and regular use in more recent studies, for example Bletilla striata (Pan-pan et al., 2018), Petuna axillaris (Regalado et al., 2017), and Populus hopeiensis (Wu et al., 2020). In comparison, oryzalin has been used successfully to create polyploid lines of woody and semi-woody plants including Rosa (Kermani et al., 2003), Rhododendron (Hebert et al., 2010), Chaenomeles (Stanys et al., 2006), Hypericum (Meyer et al., 2009), and Acer platanoides (Lattier et al., 2013; Table 1). Further, oryzalin has been shown to be more efficient than colchicine for in vitro chromosome doubling for Chaenomeles japonica (Stanys et al., 2006), Rhododendron sp. (Väinölä, 2000), Watsonia lepida (Ascough et al., 2008), and Ranunculus asiaticus (Dhooghe et al., 2009a).

The concentration and length of exposure to antimitotic compounds are factors that are consistently investigated. While low levels of exposure are non-effective and high levels are 
lethal, the interaction between exposure time and concentration is not fully understood. For oryzalin, Meyer et al. (2009) found that the concentration significantly affected survival and ploidy induction of Hypericum sp. callus; however, length of exposure had no effect. Similarly, concentration and exposure duration of oryzalin were not significant factors in inducing polyploidy in Rhododendron hybrids (Väinölä, 2000). For Populus hopeiensis both concentration and exposure time to colchicine were highly significant factors influencing polyploidy. For Rosa sp. the relationship between concentration and exposure time to oryzalin seemed to be dependent upon tissue type (Kermani et al., 2003; Allum et al., 2007). Kermani et al. (2003) found reduced duration to oryzalin was required when using $1 \mathrm{~mm}$ nodal segments compared to shoot apices. Similarly, Allum et al. (2007) found nodal segment size influenced exposure duration to oryzalin. Allum et al. (2007) suggested that to ensure chromosome doubling, exposure time should be long enough to maximize the number of cells in mitosis and exposure to antimitotic compounds.

Solubility in relation to binding affinity to tubulin is another factor to consider when selecting an antimitotic agent. For example, colchicine is highly soluble in water $(>1.5 \mathrm{M})$ and can be readily added to standard culture media, but has a relatively low binding affinity to plant tubulins (Morejohn et al., 1987). In contrast, dinitroanilines are relatively insoluble in aqueous solutions, with oryzalin reaching saturation at $<7.5 \mu \mathrm{M}$ in water, but often bind to plant tubulins at concentrations below $500 \mathrm{nM}$ (Morejohn et al., 1987). Interestingly, working concentrations of oryzalin commonly used for polyploid induction regularly exceed both binding affinity and solubility concentrations (Table 1). While species differences in oryzalin specificity to tubulins may account for some variability (Ma et al., 2010), the interaction between exogenous oryzalin concentrations and intracellular tubulin remain unclear.

The most common method for the in vitro application of antimitotic inhibitors is via treatment in a liquid solution or media, followed by recovering tissues on a regeneration or propagation medium, though, in some cases, the addition of antimitotic agents to solidified media has been successful for developing polyploids. For Hypericum sp., polyploids were developed after exposing regenerative callus to oryzalin in a liquid media for 3 to 9 days (Meyer et al., 2009). In contrast, Dhooghe et al. (2009a) used solid media containing oryzalin to induce polyploidy in Ranunculus asiaticus.

Commonly, the antimitotic agents are added to media with similar composition to the in vitro growth media. It is possible that media components may also interact with antimitotic agents to influence chromosome doubling. For example, the efficiency of dinitroanilines binding to $\alpha$-tubulin is significantly influenced by $\mathrm{pH}$ and sucrose (Morejohn et al., 1987; Hugdahl and Morejohn, 1993). In tubulin binding assays, Hugdahl and Morejohn (1993), showed a threefold increase in oryzalin binding affinity when $\mathrm{pH}$ was increased from 6.0 to 7.0. Further, these authors noted that sucrose may alter the interaction between oryzalin and tubulin (Hugdahl and Morejohn, 1993). Sucrose and pH are two key components in plant tissue culture media and need to be considered when developing in vitro polyploidy protocols.
Plant growth regulators may also interact with antimitotic agents. Lattier et al. (2013) showed the addition of the cytokinin 6-benzyl amino purine (BA) to medium containing oryzalin increased shoot mortality at higher oryzalin concentrations. They suggested that BA may act to increase cell cycling, producing cells that more quickly transition from metaphase to anaphase where they may be susceptible to oryzalin (Lattier et al., 2013). Considering media components when developing in vitro ploidy manipulation protocols may maximize chromosome doubling efficiencies.

\section{INFLUENCE OF PRE AND POST-TREATMENTS}

In some cases, pre-treatments have been utilized to facilitate synchronizing the cell cycle to maximize the effect of antimitotic agents. Lattier et al. (2013) found for nodal segments of Acer platanoides, a 7-day culture on media supplemented with a combination of $4 \mu \mathrm{M}$ BAP and $1 \mu \mathrm{M}$ IAA prior to oryzalin treatments, significantly increased the number of stable tetraploids recovered. Similarly, Wu et al. (2020) found leaf blades of Populus hopeiensis cultured on $1.78 \mu \mathrm{M}$ BAP, $0.07 \mu \mathrm{M}$ TDZ and $0.53 \mu \mathrm{M}$ IAA for 7 days prior to colchicine treatment significantly increased polyploid induction. In contrast, for Tulipa gesneriana, incubating stem disks for 2 weeks on media supplemented with $4 \mu \mathrm{M}$ BAP, $15 \mu \mathrm{M}$ 2-iP, and $4 \mu \mathrm{M}$ NAA did not influence polyploid induction (Chauvin et al., 2005).

Culture conditions following treatment with antimitotic agents have also been shown to influence chromosome doubling. Niimi et al. (2015) found that culturing Raphanobrassica hybrids on media containing either silver nitrate $\left(\mathrm{AgNO}_{3}\right)$ or aminoethoxyvinylglycine (AVG) after treatment with the mitotic inhibitor APM increased in tissue survival and polyploids. These compounds inhibit ethylene production and were shown to reduce chlorosis resulting in higher recovery rates of tissues affected by APM.

\section{CROP IMPROVEMENT}

The effects of whole genome duplication may cause significant genetic changes in gene expression and gene function and may have significant effects for crop breeding and development. The specific effects of polyploidy may vary greatly between species and polyploid induction events.

Morphological changes are regularly reported in response to chromosome doubling. Increased stomatal size has been commonly used to identify chromosome doubling (Stanys et al., 2006; Dhooghe et al., 2010). Traits such as leaf size and thickness (Väinölä, 2000; Dunn and Lindstrom, 2007), inflorescence size and number (Kermani et al., 2003; Allum et al., 2007; Oates et al., 2012) internode length and plant height (Liu et al., 2007; Oates et al., 2012) have all been reported to be influenced by chromosome doubling. Increases in polyploidy have also been linked to an increase in size and biomass. For example, 
many grasses used as bioenergy feedstocks are polyploids (Lambertini, 2019).

In vitro polyploid induction may also facilitate the development of improved, non-invasive, seedless nursery crops. One of the most effective means for developing seedless plants is to create triploids (plants with three sets of chromosomes) by crossing a diploid with artificially induced tetraploid (Ranney, 2006). This approach has been successful for several species including Miscanthus sinensis (Rounsaville et al., 2011).

Hybrid sterility, also referred to as chromosomal sterility, often occurs due to improper chromosome pairing during meiosis as a result of structural differences in parental chromosomes (Ranney, 2006; Contreras et al., 2007). In many cases, doubling chromosomes of sterile hybrids, thereby developing allotetraploids, provides a homolog for chromosomes to pair with during meiosis and restores fertility. Doubling chromosomes has been successful in restoring fertility in the wide hybrids Rhododendron 'Fragrant Affinity' (Contreras et al., 2007), × Chitalpa tashkentensis (Olsen et al., 2006), and Rudbeckia sp. (Oates et al., 2012). Further, chromsosome doubling restored fertility to the interspecific triploid bioenergy grass, Miscanthus $\times$ giganteus (Touchell and Ranney, 2012).

\section{OPPORTUNITIES FOR THE FUTURE}

The future development and improvement of efficient, reliable and repeatable in vitro ploidy manipulation protocols may consider multiple variables:

(1) The development of effective and efficient regeneration systems. Regeneration through organogenesis and somatic embryogenesis can facilitate reducing cytochimeras and increase the production of homogeneous polyploids. However, regeneration systems have been developed for a small number of crops and in most cases polyploid induction studies have focused on using shoot apices or nodal segments.

(2) Exploring the diversity of mitotic inhibitors. In vitro ploidy manipulation studies have focused primarily on a small

\section{REFERENCES}

Allum, J. F., Bringloe, D. H., and Roberts, A. V. (2007). Chromosome doubling in a Rosa rugosa Thunb. hybrid by exposure of in vitro nodes to oryzalin: the effects of node length, oryzalin concentration and exposure time. Plant Cell Rep. 26, 1977-1984. doi: 10.1007/s00299-007-0411-y

Anthony, R. G., and Hussey, P. J. (1999). Double mutation in Eleusine indica tubulin increases the resistance of transgenic maize calli to dinitroaniline and phophorothiomidate herbicides. Plant J. 18, 669-674. doi: 10.1046/j.1365-313x. 1999.00484.x

Artichart, P. (2013). Polyploid induction by colchicine treatments and plant regeneration of Dendrobium chrysotoxum. Thai J. Agric. Sci. 46, 59-63.

Ascough, G. D., van Staden, J., and Erwin, J. E. (2008). Effectiveness of colchicine and oryzalin at inducing polyploidy in Watsonia lepida N.E. Brown. Hortscience 43, 2248-2251. doi: 10.21273/hortsci.43.7.2248

Bairu, M. W., Stirk, W. A., Dolezal, K., and Staden, J. V. (2007). Optimizing the micropropagation protocol for the endangered Aloe polyphylla: Can meta-topolin and its derivatives serve as replacement for benzyladenine and number of antimitotic agents. Considering the diversity in the structural range of antimicrotubule agents, especially herbicides, there is significant opportunity to further explore their efficacy in in vitro ploidy manipulation.

(3) Considering interaction with media components. In vitro procedures are often species-specific and each taxa requires unique media compositions. The effect of the interactions of media components on polyploid induction has received little attention. Considering $\mathrm{pH}$, sucrose, and growth regulators may interact with mitotic inhibitors it may be important to integrate in vitro protocols with ploidy manipulation.

(4) Refining cultures conditions before and after treatments. Some studies have found pre- and post-treatments beneficial in maximizing survival and homogeneous polyploids. These treatments may act to synchronize the cell cycle and moderate physiological responses to stresses imposed by mitotic inhibitors.

\section{AUTHOR CONTRIBUTIONS}

DT was the lead author in the preparation of the manuscript. All authors were involved in discussing, formulating, and editing the manuscript.

\section{FUNDING}

This study was supported by North Carolina Department of Agriculture - Bioenergy Research Initiative, Spring Meadow, Star Roses and Plants, Nursery, Darwin Perennials, The J. Frank Schmidt Family Charitable Foundation.

\section{ACKNOWLEDGMENTS}

We would like to thank the staff at the NCSU Mountain Crop Improvement (MCI) Lab (including Andra Nus, Nathan Lynch, and Thomas Eaker).

zeatin? Plant Cell Tissue Organ. Cult. 90, 15-23. doi: 10.1007/s11240-007-92334

Banyai, W., Sangthong, R., Karaket, N., Inthima, P., Mii, M., and Supaibulwatana, K. (2009). Overproduction of artemisinin in tetraploid Artemisia annua L. Plant Biotechnol. 27, 427-433. doi: 10.5511/plantbiotechnology.10.0726a

Bartels, P., and Hilton, J. (1973). Comparison of trifluralin, oryzalin, pronamide, propham, and colchicine treatments on microtubules. Pest. Biochem. Physiol. 3, 462-472. doi: 10.1016/0048-3575(73)90072-2

Blakeslee, A., and Avery, A. (1937). Methods of inducing doubling of chromosomes in plants by treatment with colchicine. J. Hered. 28, 393-411. doi: 10.1093/ oxfordjournals.jhered.a104294

Blume, Y. B., Krasylenko, Y. A., Demchuk, O. M., and Yemets, A. I. (2013). Tubulin tyrosine nitration regulates microtubule organization in plant cells. Front. Plant Sci. 4:530. doi: 10.3389/fpls.2013.00530

Cai, D.-Y., Lin, J.-H., and Deng, J.-P. (2016). Studies of propyzamide on polyploidy mutation of Vitas davidii. J. Cent. S. Univ. For. Technol. 7, 103-108.

Chandanie, M. A., Singh, S. K., Sindhu, S. S., Singh, A., Tomar, S. M. S., and Prasad, K. V. (2011). Efficacy of oryzalin as a potent chemical for in vitro induction of 
polyploids in Asiatic lily ( Lilium hybrid L.) var. Polyanna. Indian J. Genet. 71, $262-268$.

Chauvin, J. E., Label, A., and Kermarrec, M. P. (2005). In vitro chromosomedoubling in tulip ( Tulipa gesneriana L.). J. Hortic. Sci. Biotechnol. 80, 693-698. doi: 10.1080/14620316.2005.11512000

Chen, L.-P., Wang, Y.-J., and Zhao, M. (2006). In vitro induction and characterization of tetraploid Lychnis senno Siebold et Zucc. Hortscience 41, 759-761. doi: 10.21273/hortsci.41.3.759

Chu, Z., Chen, J., Nyporko, A., Han, H., Yu, Q., and Powles, S. (2018). Novel $\alpha$-tubulin mutations conferring resistance to dinitroaniline herbicides in Lolium rgidum. Front. Sci. 9:97. doi: 10.3389/fpls.2018. 00097

Cohen, D., and Yao, J.-L. (1996). In vitro chromosome doubling of nine Zantedeschia cultivars. Plant Cell Tissue Organ. Cult. 47, 43-49. doi: 10.1007/ BF00224065

Comai, L. (2005). The advantages and disadvantages of being polyploid. Nature 6, 836-846. doi: 10.1038/nrg1711

Contreras, R. N., and Meneghelli, L. (2016). In vitro chromosome doubling of Prunus laurocerasus 'Otto Luyken' and 'Schipkaensis'. Hortscience 51, 1463-1466. doi: 10.21273/hortsci11329-16

Contreras, R. N., Ranney, T. G., and Tallury, S. P. (2007). Reproductive behavior of diploid and allotetraploid Rhododendron L. 'Fragrant Affinity'. Hortscience 42, 31-34. doi: 10.21273/hortsci.42.1.31

Darzynkiewicz, Z., Halicka, H. D., Zhao, H., and Podhorecka, M. (2011). Cell synchronization by inhibitors of DNA replication induces replication stress and DNA damage response: analysis by flow cytometry. Methods Mol. Biol. 761, 85-96. doi: 10.1007/978-1-61779-182-6_6

de Carvalho, J. F. R. P., de Carvahlo, C. R. P., and Otoni, W. C. (2005). In vitro induction of polyploidy in annatto (Bixa orellana ). Plant Cell Tissue Organ. Cult. 80, 69-75. doi: 10.1007/s11240-004-8833-5

Dermen, H. (1953). Periclinal cytochimeras and origin of tissues in stem and leaf of peach. Am. J. Bot. 40, 154-158.

Dhooghe, E., Denis, S., Eeckhaut, T., Reheul, D., and Van Labeke, M.-C. (2009a). In vitro induction of tetraploids in ornamental Ranunculus. Euphytica 168, 33-40. doi: 10.1007/s10681-008-9876-1

Dhooghe, E., Grunewald, W., Leus, L., and Van Labeke, M.-C. (2009b). In vitro polyploidisation of Helleborus species. Euphytica 165, 89-95. doi: 10.1007/ s10681-008-9763-9

Dhooghe, E., Laere, K. V., Eeckhaut, T., Leus, L., and Huylenbroeck, J. V. (2010). Mitotic chromosome doubling of plant tissues in vitro. Plant Cell Tissue Organ. Cult. 104, 359-373. doi: 10.1007/s11240-010-9786-5

Dunham, H. H., and Banta, A. M. (1940). Some effects of colchicine on heredity in Daphnia longispina. Genetics 25, 310-325.

Dunn, B. L., and Lindstrom, J. T. (2007). Oryzalin-induced chromosome doubling in Buddleja to facilitate interspecific hybridization. Hortscience 42, 1326-1328. doi: 10.21273/hortsci.42.6.1326

Ebrahimzadeh, H., Soltanloo, H., Shariatpanahi, M. E., Eskandari, A., and Ramezanpour, S. S. (2018). Improved chromosome doubling of parthenogenetic gaploid plants of cucumber ( Cucumis sativus L.) using colchicine, trifluralin, and oryzalin. Plant Cell Tissue Organ. Cult. 135, 407-417. doi: 10.1007/s11240-018-1473-y

Eeckhaut, T., Samijn, G., and Van Bockstaele, E. (2002). In vitro polyploidy induction in Rhododendron simsii hybrids. Acta Hortic. 572, 43-49. doi: 10. 17660/actahortic.2002.572.4

Eeckhaut, T., Werbrouck, S., Leus, L., Van Bockstaele, E., and Debergh, P. (2004). Chemically induced polyploidization in Spathiphyllum wallisii Regel through somatic embryogenesis. Plant Cell Tissue Organ. Cult. 78, 241-246. doi: 10. 1023/b:ticu.0000025659.19232.04

Emsweller, S. L., and Ruttle, M. L. (1941). Induced polyploidy in floriculture. Am. Nat. 75, 310-328. doi: 10.1086/280967

Gallone, A., Hunter, A., and Douglas, G. C. (2014). Polyploid induction in vitro using colchicine and oryzalin on Hebe 'Oratia Beauty': production and characterization of vegetative traits. Sci. Hortic. 179, 59-66. doi: 10.1016/j. scienta.2014.09.014

Gantait, S., Mandal, N., Bhattacharyya, S., and Das, P. K. (2011). Induction and identification of tetraploids using in vitro colchicine treatment of Gerbera jamesonii Bolus cv. Sciella. Plant Cell Tissue Organ. Cult. 106, 485-493. doi: 10.1007/s11240-011-9947-1
Geoffriau, E., Kahane, R., Bellamy, C., and Rancillac, M. (1997). Ploidy Stability and in vitro chromosome doubling in gynogenic clones of onion (Allium cepa L.). Plant Sci. 28, 201-208. doi: 10.1016/s0168-9452(96)04556-6

Ghanbari, M. A., Jowkar, A., Salehi, H., and Zarei, M. (2019). Effects of polyploidization on petal characteristics and optical properties of Impatients walleriana (Hook.). Plant Cell Tissue Organ. Cult. 138, 299-310. doi: 10.1007/ s11240-019-01625-3

Giles, N. L., Armson, A., and Reid, S. A. (2009). Characterization of trifluralin binding with recombinant tubulin from Trypanosoma brucei. Parasitol. Res. 104, 893-903. doi: 10.1007/s00436-008-1271-2

Gillooly, D. A., Touchell, D. H., and Ranney, T. G. (2015). In vitro polyploid induction of Ophiopogon planiscapus. SNA Res. Conf. 60, 181-185.

Griesbach, R. J. (1990). A fertile tetraploid Anigozanthis hybrid produced by in vitro colchicine treatment. Hortscience 25, 802-803. doi: 10.21273/hortsci. 25.7.802

Gu, X. F., Yang, A. F., Meng, H., and Zhang, J. R. (2005). In vitro induction of tetraploid plants from diploid Zizyphus jujube Mill. Cv.Zhanhua. Plant Cell Rep. 24, 671-676. doi: 10.1007/s00299-005-0017-1

Hannweg, K., Sippel, A., and Bertling, I. (2013). A simple and effective method for the micropropagation and in vitro induction of polyploidy and the effect on floral characteristics of the South African iris, Crocosmia aurea. S. Afr. J. Bot. 88, 357-372.

Hannweg, K., Steyn, W., and Bertling, I. (2016a). In-vitro induced tetraploids of Plectranthus esculentus are nematode-tolerant and have enhanced nutritional value. Euphytica 207, 343-351. doi: 10.1007/s10681-015-1547-4

Hannweg, K., Visser, G., de Jager, K., and Bertling, I. (2016b). In vitroinduced polyploidy and its effect on horticultural characteristics, essential oil composition and bioactivity of Tetradenia riparia. S. Afr. J. Bot. 106, 186-191. doi: 10.1016/j.sajb.2016.07.013

Hansen, N. G. P., and Andersen, S. B. (1998). In vitro chromosome doubling with colchicine during microspore culture in wheat ( Triticum aestivum L.). Euphytica 102, 101-108.

Hebert, C. J., Touchell, D. H., Ranney, T. G., and LeBude, A. V. (2010). In vitro shoot regeneration and polyploidy induction of Rhododendron 'Frangrantissimum Improved'. Hortscience 45, 801-804. doi: 10.21273/hortsci. 45.5.801

Heinz, D. J., and Mee, G. W. P. (1970). Colchicine-induced polyploids from cell suspension cultures of sugarcane. Crop Sci. 696-699. doi: 10.2135/cropsci1970. 0011183x001000060030x

Hias, N., Leus, L., Davey, M. W., Vanderzande, S., Van Huylenbroeck, J., and Keulemans, J. (2017). Effect of polyploidization in two apple (Malus x doemestica ) genotypes. Hortic. Sci. 44, 55-63. doi: 10.17221/7/2016-hortsci

Hugdahl, J. D., and Morejohn, L. C. (1993). Rapid and reversible high-affinity binding of the dinitroaniline herbicide oryzalin to tubulin from Zea mays L. Plant Physiol. 102, 725-740. doi: 10.1104/pp.102.3.725

Hussey, G., and Hypher, A. (1978). Clonal propagation of sugar beet plants and the formation of polyploids by tissue culture. Ann. Bot. 42, 477-479. doi: 10.1093/oxfordjournals.aob.a085483

Javadian, N., Karimzadeh, G., Sharifi, M., Moieni, A., and Behmanesh, M. (2017). In vitro polyploid induction: changes in morphology, podophyllotoxin biosynthesis, and the expression of the related genes in Linum album (Linaceae). Planta 245, 1165-1178. doi: 10.1007/s00425-017-2671-2

Jiang, Y., Liu, S., Hu, J., He, G., Liu, Y., Chen, X., et al. (2020). Polyploidization of Plumbago auriculate Lam. In vitro and its characterization including cold tolerance. Plant Cell Tissue Organ. Cult. 140, 315-325. doi: 10.1007/s11240019-01729-w

Jovanović, A. M., Durst, S., and Nick, P. (2010). Plant cell division is specifically affected by nitrotyrosine. J. Exp. Bot. 61, 901-909. doi: 10.1093/jxb/erp369

Kadota, M., and Niimi, Y. (2002). In vitro induction of tetraploid plantsfrom a diploid Japanese pear cultivar ( Pyrus pyrifolia N. cv. Hosui). Plant Cell Rep. 21, 282-286. doi: 10.1007/s00299-002-0509-1

Kaensaksiri, T., Soontornchainaksaeng, P., Soonthorncharennon, N., and Prathanturarug, S. (2011). In vitro induction of polyploidy in Centella asiatica (L.) Urban. Plant Cell Tissue Organ. Cult. 107, 187-194. doi: 10.1007/s11418-013-0761-4

Kehr, A. (1996). Woody plant polyploidy. Am. Nurseryman 183, 38-47.

Kermani, M. J., Sarasan, V., Roberts, A. V., Yokoya, K., Wentworth, J., and Sieber, V. K. (2003). Oryzalin-induced chromosome doubling in Rosa and its effect 
on plant morphology and pollen viability. Theor. Appl. Genet. 107, 1195-1200. doi: 10.1007/s00122-003-1374-1

Khosravi, P., Kermani, M. J., Nematzadeh, G. A., Bihamta, M. R., and Yokoya, K. (2008). Role of mitotic inhibitors and genotype on chromosome doubling of Rosa. Euphytica 160, 267-275. doi: 10.1007/s10681-007-9571-7

Kitamura, S., Akutsu, M., and Okazaki, K. (2009). Mechanism of action of nitrous oxide gas applied as a polyploidizing agent during meiosis in lilies. Sex. Plant Reprod. 22, 9-14. doi: 10.1007/s00497-008-0084-x

Klekowski, E. J. (2003). Plant clonality, mutation, diplontic selection and mutational meltdown. Biol. J. Linn. Soc. 79, 61-67. doi: 10.1046/j.1095-8312. 2003.00183.x

Lambertini, C. (2019). Why are tall-statured energy grasses of polyploid species complexes potentially invasive? A review of their genetic variation patterns and evolutionary plasticity. Biol. Invasions 21, 3019-3041. doi: 10.1007/s10530019-02053-2

Lattier, J. D., Touchell, D. H., Ranney, T. G., and Smith, J. C. (2013). Micropropagation and Polyploid Induction of Acer platanoides 'Crimson Sentry'. J. Environ. Hortic. 31, 246-252.

Leung, Y. Y., Hui, L. L. Y., and Kroaus, V. B. (2015). Colchicine - update on mechanisms of action and therapeutic uses. Semin. Arthritis Rheum. 45, 341-350. doi: 10.1016/j.semarthrit.2015.06.013

Lipka, E., and Müller, S. (2014). Nitrosative stress triggers microtubule reorganization in Arabidopsis thaliana. J. Exp. Bot. 65, 4177-4189. doi: 10.1093/ jxb/eru194

Liu, G., Li, Z., and Bao, M. (2007). Colchicine-induced chromosome doubling in Platanus acerifolia and its effect on plant morphology. Euphytica 157, 145-154. doi: 10.1007/s10681-007-9406-6

Ma, C., Tran, J., Gu, F., Ochoa, R., Li, C., Sept, D., et al. (2010). Dinitroaniline activity in Toxoplasma gondii expressing wild-type or mutant $\alpha$-tubulin. Antimicrob. Agents Chemother. 54, 1453-1460. doi: 10.1128/AAC.01150-09

Meyer, E. M., Touchell, D. H., and Ranney, T. G. (2009). In vitro shoot regeneration and polyploid induction from leaves of Hypericum species. Hortscience 44, 1957-1961. doi: 10.21273/hortsci.44.7.1957

Mitrofanova, I. V., Zilbervarg, I. R., Yemets, A. I., Mitrofanova, O. V., and Blume, Y. B. (2003). The effect of dinitroaniline and phosphorothioamidate herbicides on polyploidisation in vitro of Nepeta plants. Cell Biol. Int. 27, 229-231. doi: 10.1016/S1065-6995(02)00317-7

Morejohn, L. C., Bureau, T. E., Molebajer, J., Bajer, A. S., and Fosket, D. E. (1987). Oryzalin, a dinitroaniline herbicide, binds to plant tubulin and inhibits microtubule polymerization in vitro. Planta 172, 252-264. doi: 10.1007/ BF00394595

Morejohn, L. C., Bureau, T. E., Tocchi, L. P., and Fosket, D. E. (1984). Tubulins from different higher plant species are immunologically nonidentical and bind colchicine differentially. Proc. Natl. Acad. Sci. U.S.A. 81, 1440-1444. doi: 10. 1073/pnas.81.5.1440

Murashige, T., and Nakano, R. (1966). Tissue culture as a potential tool in obtaining polyploid plants. J. Hered. 57, 114-118.

Murthy, J. V., Kim, H.-H., Hanesworth, V. R., Hugdahl, J. D., and Morejohn, L. C. (1994). Competitive inhibition of high-affinity oryzalin binding to plant tubulin by the phosphoric amide herbicide amiprophos-methyl. Plant Physiol. 105, 309-320. doi: 10.1104/pp.105.1.309

Nadler, J. D., Pooler, M., Olsen, R. T., and Coleman, G. D. (2012). In vitro induction of polyploidy in Cercis glabra Pamp. Sci. Hortic. 148, 126-130. doi: 10.1016/j. scienta.2012.09.024

Nasr, M. L., Habib, H. M., Ibrahim, I. A., and Kapiel, T. Y. (2004). "In vitro induction of autotetraploid watermelons using colchicine and four dinitroaniline compounds," in Proceedings of the International Conference On Engineering \& Application, Sharm Elsheik. doi: 10.13140/2.1.3144. 3840

Neill, S. J., Desikan, R., and Hancock, J. T. (2003). Nitric oxide signaling in plants. New Phytol. 159, 11-35.

Niimi, H., Wantanabe, M., Serizawa, H., Koba, T., Nkamura, I., and Mii, M. (2015). Amiprophosmethyl-inducedeffecient in vitro production of polyploids in rhapanobrassica with the aid of aminoethoxyvinylglycin (AVG) in the culture medium. Breeed. Sci. 65, 396-402. doi: 10.1270/jsbbs.65.396

Nilanthi, D., Chen, X.-L., Zhao, F.-C., Yang, Y.-S., and Wu, H. (2009). Induction of tetraploids from petiole explants through colchicine treatments in Echinaceae purpurea L. J. Biomed. Biotechnol. 2009:343485. doi: 10.1155/2009/343485
Nimura, M., Kato, J., Horaguchi, H., Mii, M., Sakai, K., and Katoh, T. (2006). Induction of fertile amphidiploids by artificial chromosome-doubling in interspecific hybrid between Dianthus caryophyllus L. and D. japonicas Thunb. Breeed. Sci. 56, 303-310. doi: 10.1270/jsbbs.56.303

Noori, S. A. S., Norouzi, M., Karimzadeh, G., Shirkool, K., and Niazian, M. (2017). Effect of colchicine-induced polyploidy on morphological characteristics and essential oil composition of ajowan ( Trachyspermum ammi L.). Plant Cell Tissue Organ Cult. 130, 543-551. doi: 10.1007/s11240-017-1245-0

Notsuka, K., Tsurs, T., and Shiraishi, M. (2000). Induced polyploid graps via in vitro chromosome doubling. J. Jpn. Soc. Hortic. Sci. 69, 543-551. doi: 10.2503/jjshs. 69.543

Oates, K. M., Ranney, T. G., and Touchell, D. H. (2012). Influence of Induced Polyploidy on Fertility and Morphology of Rudbeckia Species and Hybrids. Hortscience 47, 1217-1221. doi: 10.21273/hortsci.47.9.1217

Olsen, R. T., Ranney, T. G., and Viloria, Z. (2006). Reproductive behavior of induced allotetraploid x Chitalpa and in vitro embryo culture of polyploidy progeny. J. Am. Soc. Horict. Sci. 131, 716-724. doi: 10.21273/jashs.131.6.716

Palmer, I. E., Touchell, D. H., and Ranney, T. G. (2008). In vitro polyploid induction of Rudbeckia sp. SNA Res. Conf. 53, 186-189.

Pan-pan, H., Wei-xu, L., Hui-hui, L., and Zeng-xu, X. (2018). In vitro induction and identification of autotetraploid of Bletilla striata (Thunb.) Reichb.f. by colchicine treatment. Plant Cell Tissue Organ. Cult. 132, 425-432. doi: 10.1007/ s11240-017-1339-8

Parsons, J. L., Martin, S. L., James, T., Golenia, G., Boudko, E. A., and Hepworth, S. R. (2019). Polyploidization for the genetic improvement of Cannabis sativa. Front. Plant Sci. 10:476. doi: 10.3389/fpls.2019.00476

Petersen, K. K., Hagberg, P., and Kristiansen, K. (2002). In vitro chromosome doubling of Miscanthus sinensis. Plant Breed. 121, 445-450. doi: 10.1046/j. 1439-0523.2002.738314.x

Petersen, K. K., Hagberg, P., and Kristiansen, K. (2003). Colchicine and oryzalin mediated chromosome doubling in different genotypes of Miscanthus sinensis. Plant Cell Tissue Organ. Cult. 73, 137-146.

Planchais, S., Glab, N., Inzé, D., and Bergounioux, C. (2000). Chemical inhibitors: a tool for plant cell cycle studies. FEBS Lett. 476, 78-83. doi: 10.1016/s00145793(00)01675-6

Ranney, T. G. (2006). Polyploidy: From evolution to new plant development. Combined Proc. Intl. Plant Propagators Soc. 56, 137-142.

Raza, H., Jaskani, M. J., Khan, M. M., and Malik, T. A. (2003). In vitro induction of polyploids in watermelon and estimation based on DNA content. Intern. J. Agric. Biol. 5, 298-302.

Regalado, J. J., Carmona-Martin, E., Querol, V., Veléz, C. G., Encina, C. L., and Pitta-Alvarez, S. I. (2017). Production of compact petunias through polyplidization. Plant Cell Tissue Organ. Cult. 129, 61-71.

Rêgo, M. M., Rêgo, E. R., Bruckner, C. H., Finger, F. L., and Otoni, W. C. (2011). In vitro induction of autotetraploids from diploid yellow passion fruit mediated by colchicine and oryzalin. Plant Cell Tissue Organ. Cult. 107, 451-459. doi: 10.1007/s11240-011-9995-6

Ren, J., Wu, X., Song, C., Liang, Y., Gao, W., and Wang, Y. (2018). Induction of polyploid tillered onion using colchicine and pendamethalin. Sains Malaysiana 47, 2617-2624. doi: 10.17576/jsm-2018-4711-04

Rose, J. B., Kubba, J., and Tobutt, K. R. (2000). Chromosome doubling in sterile Syringa vulgaris $\mathrm{x} S$. pinnatifolia hybrids by in vitro culture of nodal explants. Plant Cell Tissue Organ. Cult. 63, 127-132.

Rounsaville, T. J., Touchell, D. H., and Ranney, T. G. (2011). Fertility and reproductive pathways in diploid and triploid Miscanthus sinensis. Hortscience 46, 1353-1357. doi: 10.21273/hortsci.46.10.1353

Sakhanokho, H. F., Rajasekaran, K., Kelley, R. Y., and Islam-Faridi, N. (2009). Induced polyploidy in diploid ornamental ginger ( Hedychium muluense R. M. Smith) using colchicine and oryzalin. Hortscience 44, 1809-1814. doi: 10 21273/hortsci.44.7.1809

Sattler, M. C., Carvalho, C. R., and Clarindo, W. R. (2015). The polyploidy and its key role in plant breeding. Planta 281-296. doi: 10.1007/s00425-015-2450-x

Soltis, D. E., and Burleigh, J. D. (2009). Surviving the K-T mass extinction: new perspectives of polyploidization in angiosperms. PNAS 106, 5455-5456. doi: 10.1007/s00425-015-2450-x

Soltis, D. E., Albert, V. A., Leebans-Mack, J., Bell, C. D., Paterson, A. H., Zheng, C., et al. (2009). Polyploidy and angiosperm diversification. Am. J. Bot. 96, 336-348. doi: $10.3732 /$ ajb.0800079 
Stanys, V., Weckman, A., Staniene, G., and Duchovkis, P. (2006). In vitro induction of polyploidy in Japanese quince ( Chaenomeles japonica). Plant Cell Tissue Organ. Cult. 84, 263-268. doi: 10.1007/s11240-005-9029-3

Sun, Q., Sun, H., Li, L., and Bell, R. L. (2009). In vitro colchicine-induced polyploid plantlet production and regeneration from leaf explants of the diploid pear (Pyrus communis L.) cultivar, 'Fertility'. J. Hortic. Sci. Biotechnol. 84, 548-552. doi: 10.1080/14620316.2009.11512564

Tavan, M., Mirjalili, M. H., and Karimzadeh, G. (2015). In vitro polyploidy induction: changes in morphological, anatomical and phytochemical characteristics of Thymus persicus (Lamiaceae). Plant Cell Tissue Organ. Cult. 122, 573-583. doi: 10.1007/s11240-015-0789-0

Taylor, N. L., Anderson, M. K., Queenberry, K. H., and Watson, L. (1976). Doubling the chromosome number of Trifolium species using nitrous oxide. Crop Sci. 16, 516-518. doi: 10.2135/cropsci1976.0011183x001600040019x

The American Naturalist (1941). Symposium on theoretical and practical aspects of polyploidy in crop plants. Am. Nat. 75, 289-365. doi: 10.2135/cropscil976. 0011183x001600040019x

Thomas, J., Chen, Q., and Howes, N. (1997). Chromosome doubling of haploids of common wheat with caffeine. Genome 40, 552-558. doi: 10.1139/g97-072 doi: 10.1139/g97-072

Touchell, D. H., and Ranney, T. G. (2012). Chromosome doubling and fertility restoration in Miscanthus $\times$ giganteus. HortScience 47, S334. doi: 10.1139/g97072

Tresch, S., Plath, P., and Grossman, K. (2005). Herbicidal cyanoacrylates with antimicrotubule mechanism of action. Pest. Manag. Sci. 61, 1052-1059. doi: 10.1002/ps.1093

Trojal-Golush, A., and Skomra, U. (2013). Artificially induced polyploidization in Humulus lupulus L. and its effect on morphological and chemical traits. Breed. Sci. 63, 393-399. doi: 10.1270/jsbbs.63.393

Väinölä, A. (2000). Polyploidization and early screening of Rhododendron hybrids. Euphytica 112, 239-244.

Vaughn, K. C., and Lehnen, L. P. Jr. (1991). Mitotic disrupter herbicides. Weed Sci. 39, 450-457. doi: 10.1017/s0043174500073215

Viehmannová, I., Fernández Cusimamani, E., Bechyne, M., Vyvadilová, M., and Greplova, M. (2009). In vitro induction of polyploidy in yacon ( Smallanthus sonchifolius ). Plant Cell Tissue Organ Cult. 97, 21-25. doi: 10.1007/s11240008-9494-6
Wang, C., and Lei, J. (2012). In vitro induction of tetraploids from immature embryos through colchicine treatments in Clivia miniata Regal. J. Agric. Res. 7, 3712-3718.

Wu, J., Sang, Y., Zhou, Q., and Zhang, P. (2020). Colchicine in vitro tetraploid induction of Populus hopeiensis from leaf blades. Plant Cell Tissue Organ. Cult. 141, 339-349. doi: 10.1007/s11240-020-01790-w

Wu, J.-H., Ferguson, A. R., and Murray, B. G. (2011). Manipulation of ploidy for kiwifruit breeding: in vitro chromosome doubling in diploid Actinidia chinensis Planch. Plant Cell Tissue Organ. Cult. 106, 503-511. doi: 10.1007/s11240-0119949-z

Xu, C., Huang, Z., Liao, T., Li, Y., and Kang, X. (2016). In vitro tetraploid plants regeneration from leaf explants of multiple genotypes in Populus. Plant Cell Tissue Organ. Cult. 125, 1-9. doi: 10.1007/s11240-015-0922-0

Yang, Z., Shen, Z., Tetreault, H., Johnson, L., Friebe, B., Frazier, T., et al. (2014). Production of autopolyploid lowland switchgrass lines through in vitro chromosome doubling. Bioenergy Res. 7, 232-242. doi: 10.1007/s12155-0139364-X

Yuan, S., Su, Y., Liu, Y., Li, Z., Fang, Z., Yang, L., et al. (2015). Chromsome doubling of microspore-derived plants from cabbage (Brassica oleraceae var, capitate L.) and broccoli (Brassica oleraceae var. italica L.). Front. Plant Sci. 6:1118. doi: 10.3389/fpls.2015.01118

Zhang, Q. Y., Luo, F. X., Liu, L., and Guo, F. C. (2010). In vitro induction of tetraploids in crape myrtle ( Lagerstoemia indica L.). Plant Cell Tissue Organ. Cult. 101, 41-47. doi: 10.1007/s11240-009-9660-5

Zhang, Z., Dai, H., Xiao, M., and Liu, X. (2008). In vitro induction of tetraploids in Phlox subulata L. Euphytica 159, 59-65. doi: 10.1007/s10681-007-9457-8

Conflict of Interest: The authors declare that the research was conducted in the absence of any commercial or financial relationships that could be construed as a potential conflict of interest.

Copyright (c) 2020 Touchell, Palmer and Ranney. This is an open-access article distributed under the terms of the Creative Commons Attribution License (CC BY). The use, distribution or reproduction in other forums is permitted, provided the original author(s) and the copyright owner(s) are credited and that the original publication in this journal is cited, in accordance with accepted academic practice. No use, distribution or reproduction is permitted which does not comply with these terms. 